\title{
Molecular Characterization of Begomoviruses and DNA Satellites Associated with a New Host Spanish Flag (Lantana camara) in India
}

\author{
Avinash Marwal, Anurag Kumar Sahu, and Rajarshi Kumar Gaur \\ Department of Science, Faculty of Arts, Science and Commerce, Mody Institute of Technology and \\ Science, Lakshmangarh, Sikar, Rajasthan 332311, India \\ Correspondence should be addressed to Rajarshi Kumar Gaur; gaurrajarshi@hotmail.com
}

Received 3 October 2013; Accepted 4 November 2013

Academic Editors: D. De Medici, J. J. DeStefano, and H. E. Kaufman

Copyright (c) 2013 Avinash Marwal et al. This is an open access article distributed under the Creative Commons Attribution License, which permits unrestricted use, distribution, and reproduction in any medium, provided the original work is properly cited.

In the year 2010 yellowing of leaf vein disease was observed on Spanish Flag (Lantana camara) in Sirsa, Haryana province, India. There was no earlier report of association of begomovirus and DNA satellites with Lantana camara. Therefore, molecular characterization and understanding of the genomic analysis of begomovirus infecting Lantana camara is imperative for the pathogen diagnosis and disease management. This is the first report and molecular characterization of a begomovirus associated with its two satellites infecting a new host Lantana camara in India.

\section{Introduction}

Geminiviridae family has been classified into four genera: Mastrevirus, Curtovirus, Topocuvirus, and Begomovirus [1]. Begomovirus is the largest genus of this family. The vector is the white fly (Bemisia tabaci) that causes begomoviral infections in ornamentals, crops, and weeds and it is prevalent in the tropical and subtropical regions of the world [2]. Begomovirus is the only genus of the Geminiviridae which has bipartite genome with virus genes resident on two different circular ssDNA molecules (DNA-A, DNA-B). The mainstream of begomoviruses are bipartite nature; however, few monopartite begomoviruses have been identified that are associated with DNA satellites (alphasatellites and betasatellites). Betasatellites induces disease symptoms in the hosts from which they were isolated, whereas alphasatellites play no role in symptoms development [3]; therefore, increasing knowledge about its epidemiology, sequence diversity, and biodiversity is highly important in order to implement preventative strategies.

Spanish Flag (Lantana camara) was introduced in Europe from Central America as an ornamental plant and now is considered as one of the highest impacting invasive species throughout the globe. In India it is cultivated as an ornamental plant used for lining the boundaries of gardens as a shrub for its aesthetic beauty of small variety of attractive flowers. In the present report, we identified a begomovirus and its DNA satellites associated with Lantana camara through molecular techniques followed by its phylogenetic analysis.

\section{Material and Methods}

During the survey for begomovirus infection $20-30 \%$ yellow vein disease was observed on Lantana camara in the nursery garden of Sirsa, Haryana province, India. To investigate the potential begomoviral infection, total DNA was extracted from leaves of 32 infected plants using the cetyl trimethyl ammonium bromide (CTAB) method [4]. To confirm the presence of begomovirus in infected samples PCR was performed using a pair of degenerate primers specific to the coat protein region of begomovirus. The forward primer sequence was GGRTTDGARGCATGHGTACATG (AC 1048) and the reverse primer sequence was GCCYATRTAYAGRAAGCCMAG (AV 494) [5]. 


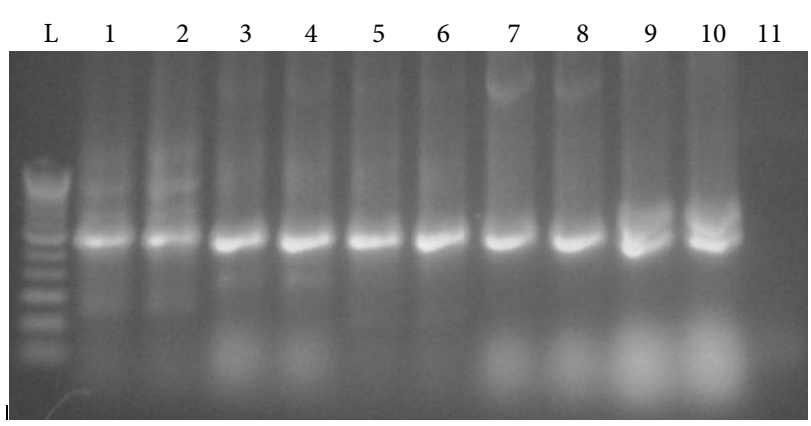

(a)

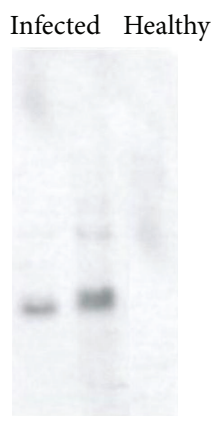

(b)

FIgURE 1: (a) Agarose gel electrophoresis of the PCR products (lanes 1-10) of coat protein gene amplified ( $550 \mathrm{bp})$ from DNA extracts prepared from infected Lantana camara plants confirming positive results of begomovirus, whereas lane 11 stands for healthy plant, L represents the $100 \mathrm{bp}$ ladder. (b) The presence of begomovirus was confirmed by Southern blot hybridization using Papaya leaf curl virus as a general probe for begomoviruses. Begomovirus from symptomatic plants hybridized with the probe, whereas samples extracted from healthy plants did not show positive results.

A typical PCR reaction contained about $100 \mathrm{ng}$ DNA template, Taq $10 \mathrm{x}$ buffers $(10 \mathrm{mM} / \mathrm{L}$ Tris- $\mathrm{HCl}, \mathrm{pH} 8.8$; $50 \mathrm{mM} / \mathrm{L} \mathrm{KCl}) 25 \mathrm{mM} / \mathrm{L} \mathrm{MgCl}_{2}, 200 \mu \mathrm{M} / \mathrm{L}$ of each dNTP, 2 units of Taq DNA polymerase, nuclease-free water, and $10 \mathrm{pM} / \mathrm{L}$ of each primer. The PCR thermal profile was prePCR denaturation at $94^{\circ} \mathrm{C}$ for $120 \mathrm{~s}$ followed by 35 cycles of denaturing at $94^{\circ} \mathrm{C}$ for $45 \mathrm{~s}$, annealing at $55^{\circ} \mathrm{C}$ for $45 \mathrm{~s}$ and extension at $72^{\circ} \mathrm{C}$ for $45 \mathrm{~s}$, and a final extension at $72^{\circ} \mathrm{C}$ for $5 \mathrm{~min}$ [6]. Sometimes satellites are also found in association with the begomovirus; therefore, to test whether a DNA satellite was associated with these isolates, a universal primer pair specific for alphasatellite and betasatellite [7, 8] was also used to amplify the putative DNA. The PCR reaction for alphasatellite and betasatellite was the same as for coat protein region of begomovirus, mentioned above in the paper, whereas the PCR thermal profile was prePCR denaturation at $94^{\circ} \mathrm{C}$ for $120 \mathrm{~s}$ followed by 35 cycles of denaturing at $94^{\circ} \mathrm{C}$ for $60 \mathrm{~s}$, annealing at $68^{\circ} \mathrm{C}$ for $60 \mathrm{~s}$ and extension at $72^{\circ} \mathrm{C}$ for $60 \mathrm{~s}$, and a final extension at $72^{\circ} \mathrm{C}$ for $5 \mathrm{~min}$. Further phylogenetic analysis was carried out for tracing evolutionary history; therefore, phylogenetic tree of the obtained sequences was generated by MEGA 4.0 software by using the neighbor-joining method with 1,000 bootstrap replications.

For further confirmation of begomovirus infectivity, Southern hybridization was performed according to the method of Kon et al. [9]. Cloned DNA-A of Papaya leaf curl virus was used to develop the radiolabeled probes as a general probe for begomoviruses. Moreover, in order to confirm the Koch's postulate for the virus and assess the infectivity and symptoms of phenotype of the variants, an infectious clone of virus isolated from Lantana camara was constructed and infected into $N$. benthamiana.

\section{Result and Discussion}

An expected amplified PCR product obtained from coat protein primer $(\sim 550 \mathrm{bp})$, alphasatellite primer $(\sim 1000 \mathrm{bp})$, and betasatellite primer ( $\sim 650 \mathrm{bp}$ ) was obtained, cloned suitably into pGEM-T vector and sequenced, having accession numbers JQ693142, KC206075, and JQ693148, respectively. All the screened 32 samples contained the begomovirus and the two satellites. The symptoms were the same, that is, yellowing of leaf veins in all the infected plants, and there wasn't any difference in symptoms in these infected plants. Sequence analysis was carried out using BLAST which revealed that the begomovirus (JQ693142) showed 99\% sequence identity with Papaya leaf curl virus (EU126823), whereas the alphasatellite (KC206075) had 94\% nucleotide identity with Guar leaf curl alphasatellite (KC305096) and the betasatellite (JQ693148) revealed $85 \%$ sequence identity with Cotton leaf curl virus (FN432359).

The positive coat protein gene PCR reaction showed the presence of begomovirus, which was further confirmed by Southern blot hybridization using Papaya leaf curl virus as a general probe for begomoviruses. All 32 samples from symptomatic plants hybridized with the probe, whereas samples extracted from nonsymptomatic plants did not show positive results (Figure 1).

The begomovirus sequenced from Lantana camara has a putative conserved domain of the Geminivirus family which encodes for coat protein of 161 amino acids having a molecular weight of $18.72 \mathrm{kDa}$. Similarly the alphasatellite isolated from Lantana camara has an arrangement typical to that of alphasatellites, containing a single ORF in the virion sense which encodes a protein similar to the replicationassociated protein (rep. a rolling-circle replication initiator protein) of alphasatellite (Table 1). An ORF C1 of betasatellite is located on the complementary-sense strand encoding a protein responsible for the movement of virus from cell to cell, thus in turn resulting in the spreading of virus throughout the plant.

Phylogenetic analysis indicates that the begomovirus infecting Lantana camara clusters with the isolate of Tomato leaf curl Bhatinda virus (Figure 2(a)) from India, whereas the isolated betasatellite clusters with Kenaf leaf curl betasatellite reported from Pakistan (Figure 2(b)) and alphasatellite forms 


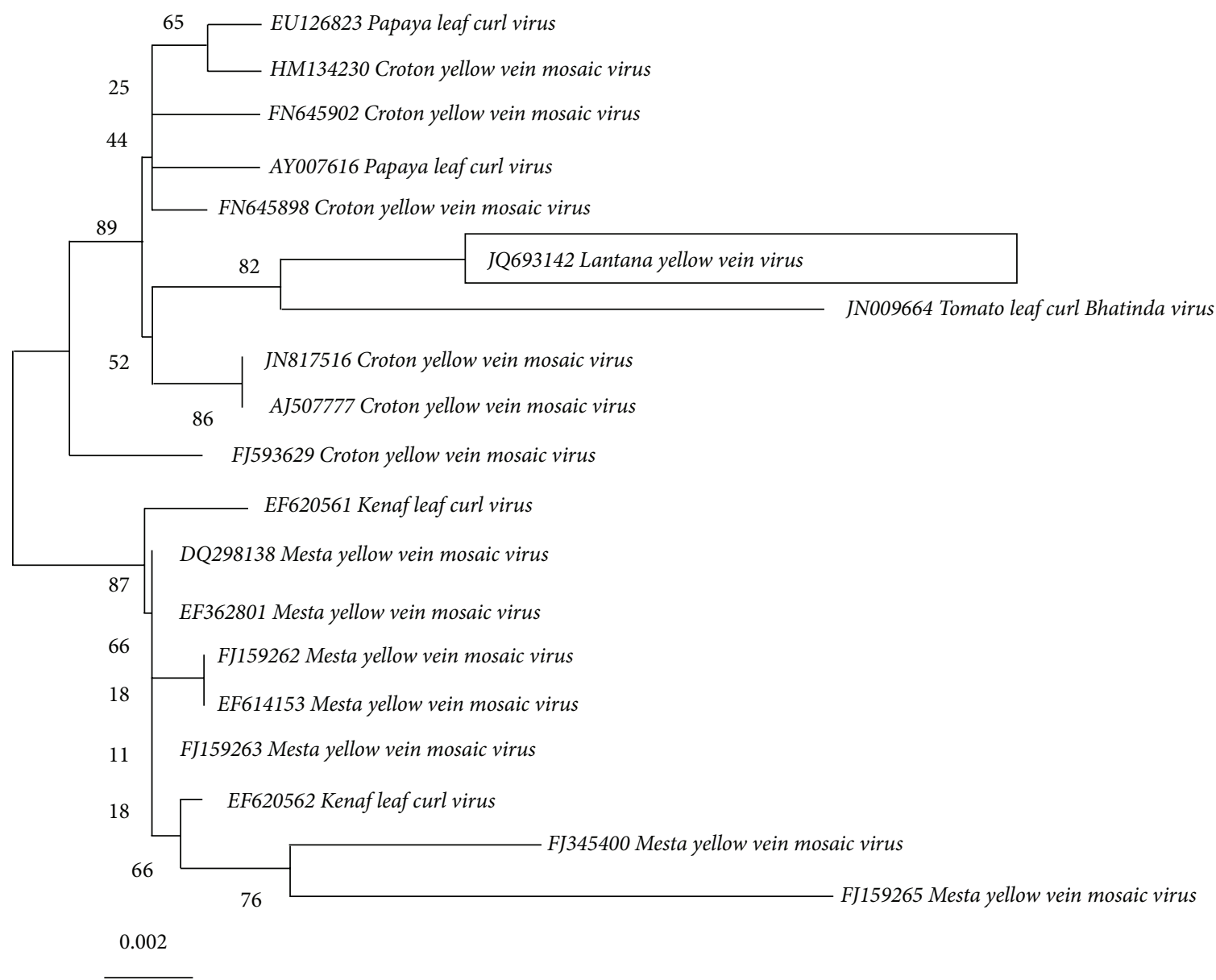

(a)

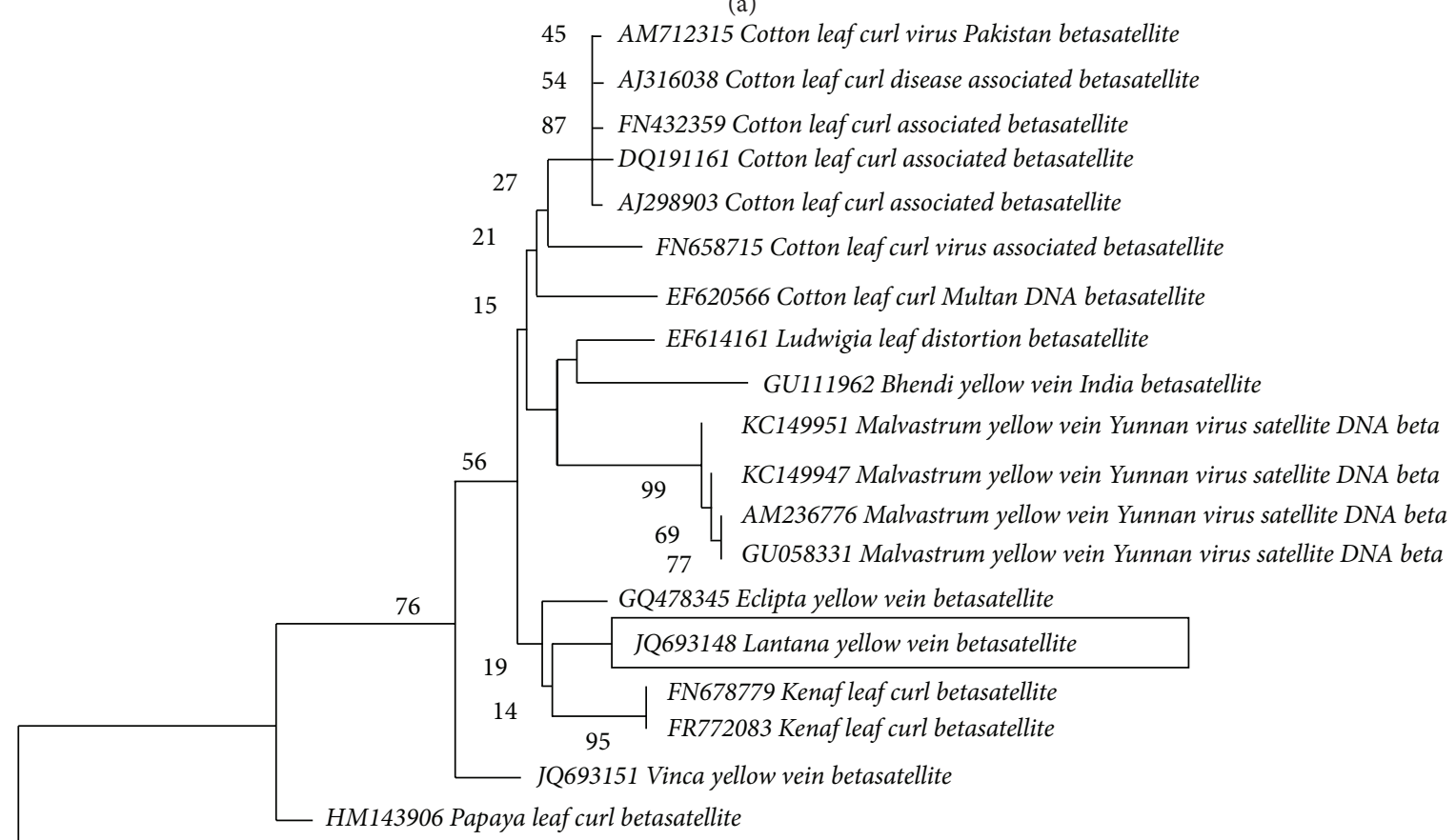

HF565180 Cotton leaf curl Multan betasatellite 


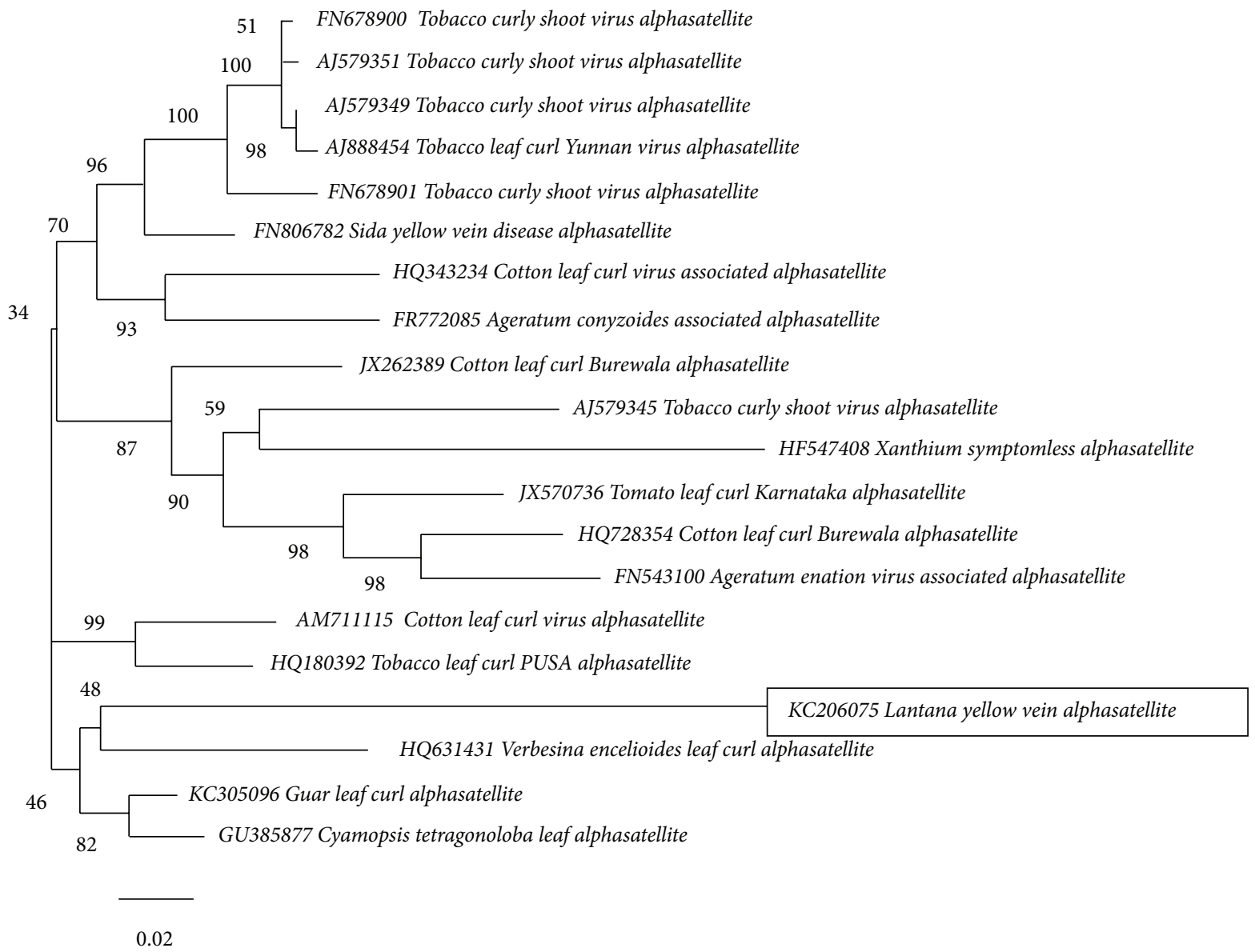

(c)

FIgURE 2: Phylogenetic dendrograms based on alignments of selected begomovirus (a), betasatellite (b), and alphasatellite (c) sequences. Begomovirus sequences used for comparison are mentioned in the respective trees. Vertical branches are arbitrary; horizontal branches are proportional to calculated mutation distances. Values at nodes indicate percentage bootstrap values (1000 replicates).

TABLE 1: Positions and coding capacity of predicted genes for the genome of begomovirus and its two satellites isolated from Lantana camara.

\begin{tabular}{|c|c|c|c|c|c|c|c|c|}
\hline Components & Description & ORFs & Strand & Frame & $\begin{array}{l}\text { Start codon } \\
\text { (nucleotide } \\
\text { coordinates) }\end{array}$ & $\begin{array}{l}\text { Stop codon } \\
\text { (nucleotide } \\
\text { coordinates) }\end{array}$ & $\begin{array}{l}\text { Predicted size } \\
\text { (no. of amino } \\
\text { acids) }\end{array}$ & $\begin{array}{c}\text { Predicted } \\
\text { molecular } \\
\text { weight }(\mathrm{kDa})\end{array}$ \\
\hline Begomovirus & Coat protein & AV1 & Sense strand & 2nd frame $(+)$ & 62 & 545 & 161 & 18.72 \\
\hline DNA- $\alpha$ & $\begin{array}{l}\text { Similar to rep. } \\
\text { protein }\end{array}$ & rep. & Sense strand & 1st frame $(+)$ & 655 & 990 & 111 & 12.70 \\
\hline DNA- $\beta$ & $\begin{array}{l}\text { Symptoms } \\
\text { inducing protein }\end{array}$ & $\mathrm{C} 1$ & Complement strand & 3rd frame $(-)$ & 288 & 389 & 33 & 4.09 \\
\hline
\end{tabular}

a clade with Verbesina encelioides leaf curl alphasatellite (Figure 2(c)) reported from India.

The infectious clone caused typical yellow vein symptoms in leaf when inoculated into $N$. benthamiana and was transmissible by white fly, confirming the begomovirus. For each experiment, nearly about $40 \mathrm{~N}$. benthamiana plants grown in an insect-free green house were taken. This resulted in the development of the same kind of symptoms as observed in naturally infected Lantana camara plants in the garden. The authenticity of infectivity assay was confirmed by using begomovirus coat protein and satellites primers in PCR.

Thus, this identification represents the possibility of a serious threat to other economically important ornamental and crop plants and there is a need for a more comprehensive study. The study will be focused on the amplification of the complete genome of the virus and its recombination analysis. This will form the basis of our future investigations. 


\section{Conclusion}

Results of these techniques will be effectively applied for disease management, crop protection, and development of quarantine strategies at state and national level in India. The possible association of a begomovirus and its two satellites that is, alpha and beta, with Spanish Flag (Lantana camara) had not been investigated previously; therefore, to the best of our knowledge, this is the first report of begomovirus and its two satellites associated with yellow vein disease of an ornamental plant Spanish Flag (Lantana camara) in India.

\section{Conflict of Interest}

All the authors have no conflict of interests to declare including any financial, personal, or other relationships with other people or organizations.

\section{Authors' Contribution}

Avinash Marwal and Anurag Kumar Sahu contributed equally to the work.

\section{Acknowledgments}

The authors would like to acknowledge to Department of Biotechnology (DBT Project no. BT/PR13129/GBD/27/197/ 2009) and Department of Science and Technology (DST Project no. SR/FT/LS-042/2009), India, for their financial support. The content and authorship of the submitted paper have been approved by all authors, and all prevailing local, national, and international regulations and conventions and normal scientific ethical practices have been respected.

\section{References}

[1] C. M. Fauquet, M. A. Mayo, J. Maniloff, U. Desselberger, and L. A. Ball, Virus Taxonomy: Eighth Report of the International Committee on Taxonomy of Viruses, Elsevier, San Diego, Calif, USA, 2005.

[2] A. Marwal, A. Sahu, P. Sharma, and R. K. Gaur, "Molecular characterizations of two begomoviruses infecting Vinca rosea and Raphanus sativus in India," Virologica Sinica, vol. 28, pp. 53-56, 2013.

[3] P. G. Markham, I. D. Bedford, L. S. Liu Sijun, and M. S. Pinner, "The transmission of geminiviruses by Bemisia tabaci," Pesticide Science, vol. 42, no. 2, pp. 123-128, 1994.

[4] J.-F. Manen, O. Sinitsyna, L. Aeschbach, A. V. Markov, and A. Sinitsyn, "A fully automatable enzymatic method for DNA extraction from plant tissues," BMC Plant Biology, vol. 5, article 23, 2005.

[5] D. B. Bela-ong and N. B. Bajet, "Molecular detection of whitefly-transmissible geminiviruses (Family Geminiviridae, Genus begomovirus) in the Philippines," Philippine Journal of Science, vol. 136, pp. 87-101, 2007.

[6] A. Marwal, A. Sahu, R. Prajapat, D. K. Choudhary, and R. K. Gaur, "First report of association of a begomovirus with the leaf curl disease of a common weed, Datura inoxia," Indian Journal of Virology, vol. 23, no. 1, pp. 83-84, 2012.
[7] R. W. Briddon, S. E. Bull, S. Mansoor, I. Amin, and P. G. Markham, "Universal primers for the PCR-mediated amplification of DNA $\beta$ : a molecule associated with some monopartite begomoviruses," Applied Biochemistry and Biotechnology B, vol. 20, no. 3, pp. 315-318, 2002.

[8] S. E. Bull, R. W. Briddon, and P. G. Markham, "Universal primers for the PCR-mediated amplification of DNA 1: a satellite-like molecule associated with begomovirus-DNA $\beta$ complexes," Applied Biochemistry and Biotechnology B, vol. 23, no. 1, pp. 83-86, 2003.

[9] T. Kon, L. M. Dolores, N. B. Bajet, S. Hase, H. Takahashi, and M. Ikegami, "Molecular characterization of a strain of squash leaf curl China virus from the Philippines," Journal of Phytopathology, vol. 151, no. 10, pp. 535-539, 2003. 

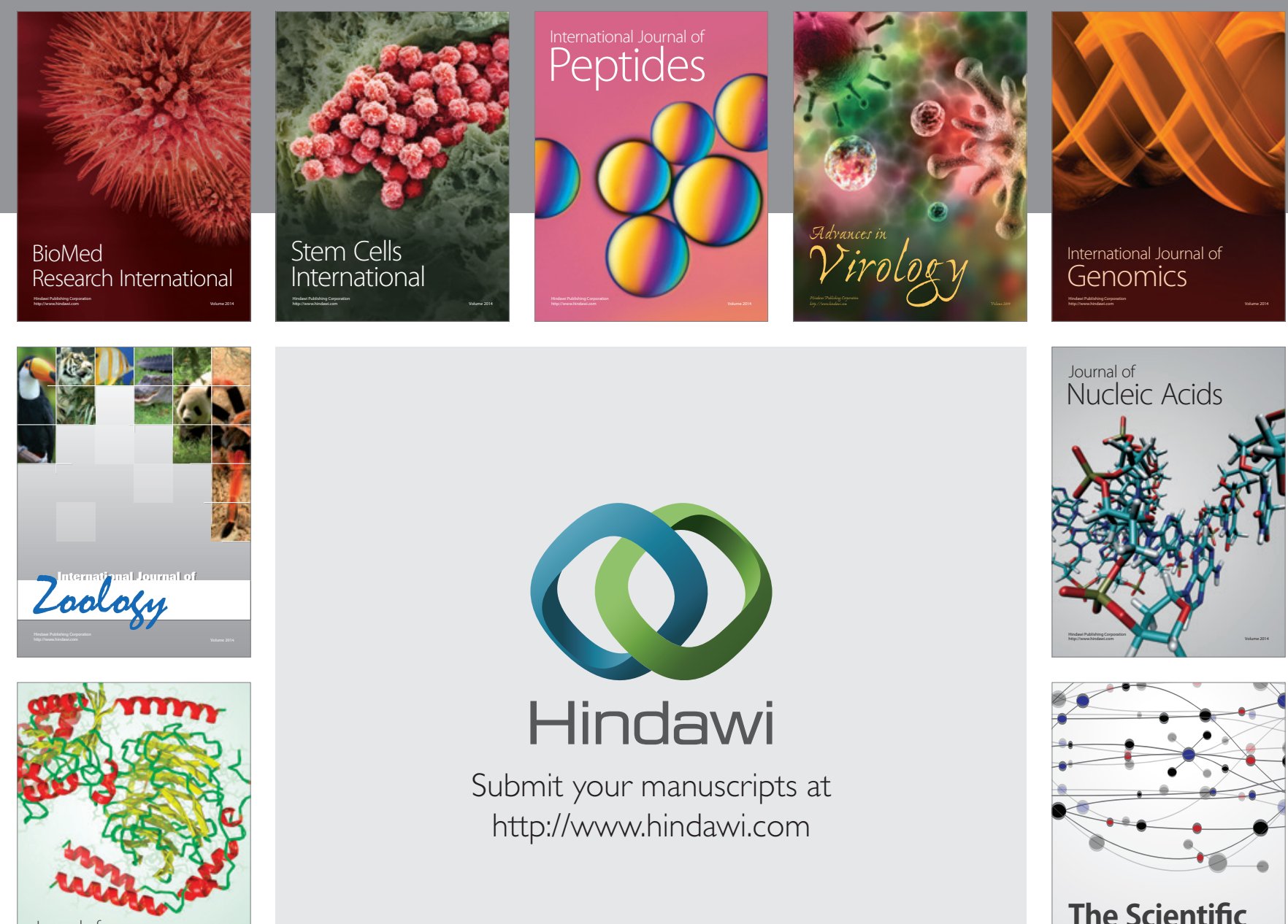

Submit your manuscripts at

http://www.hindawi.com

Journal of
Signal Transduction
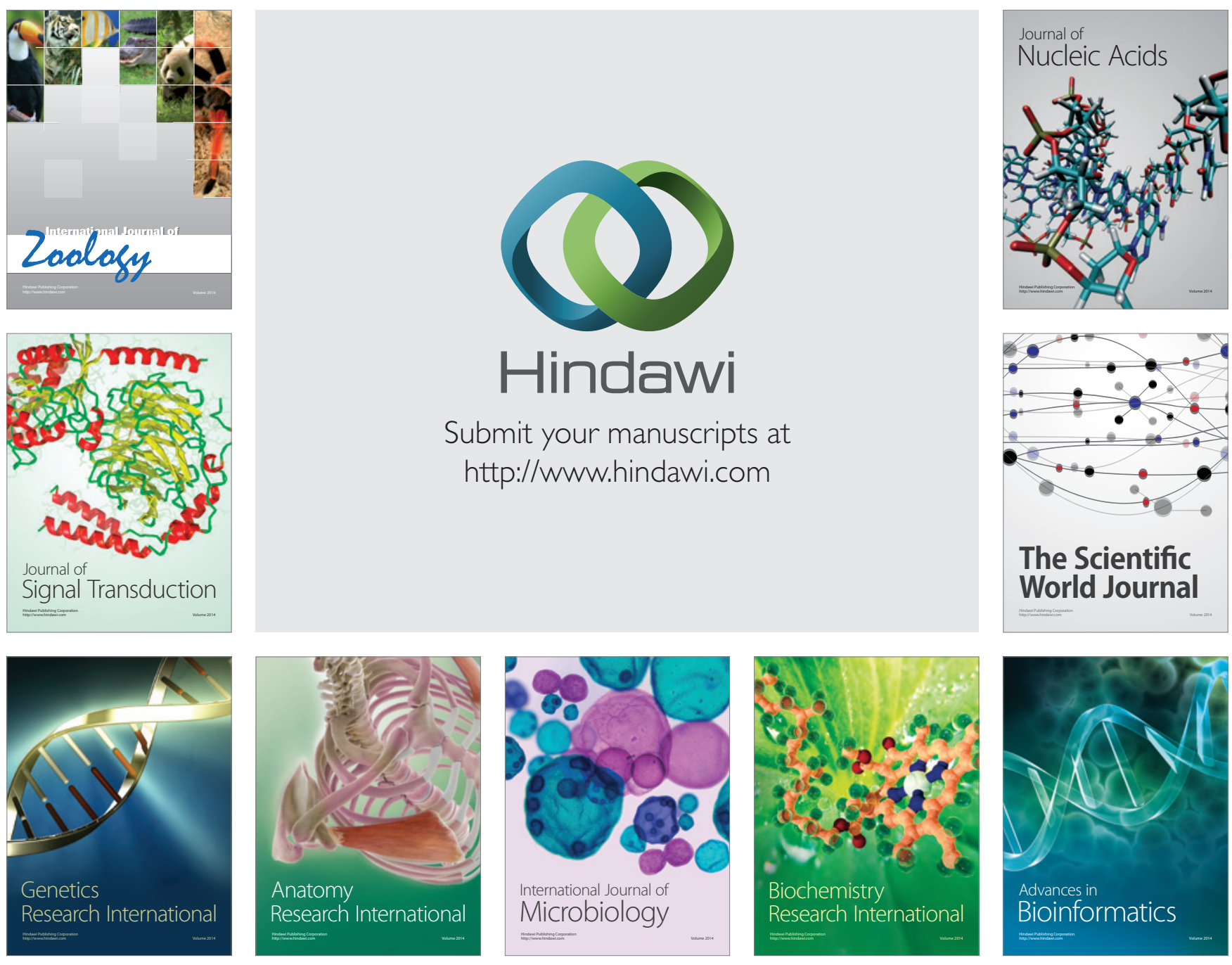

The Scientific World Journal
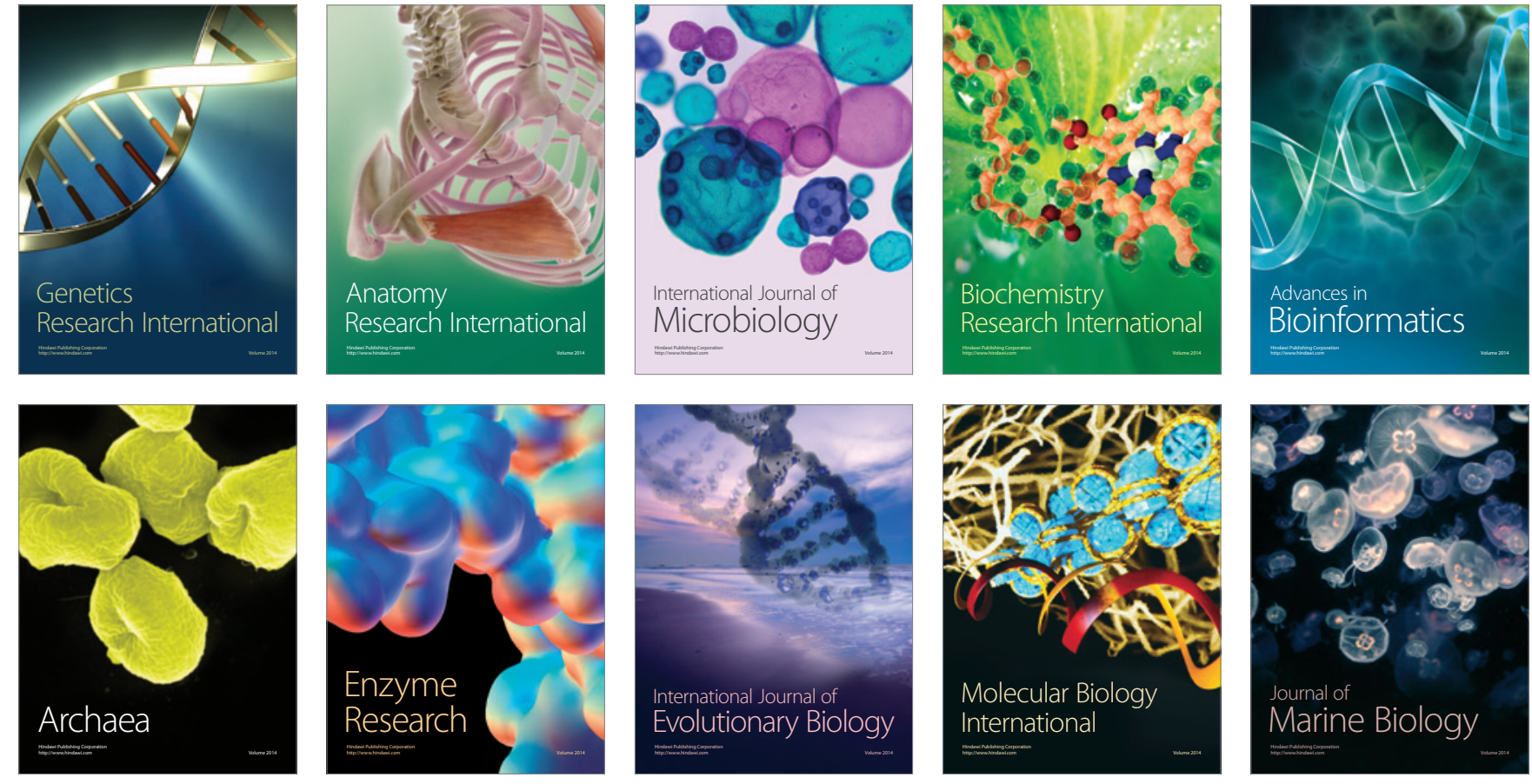